\title{
COMPARATIVE ASPECTS OF IMDIVIDUAL INDICATORS OF THE PHYSICAL DEVELOPMENT OF PRIMARY SCHOOL AGE CHILDREN
}

\author{
Moskviak N.V.
}

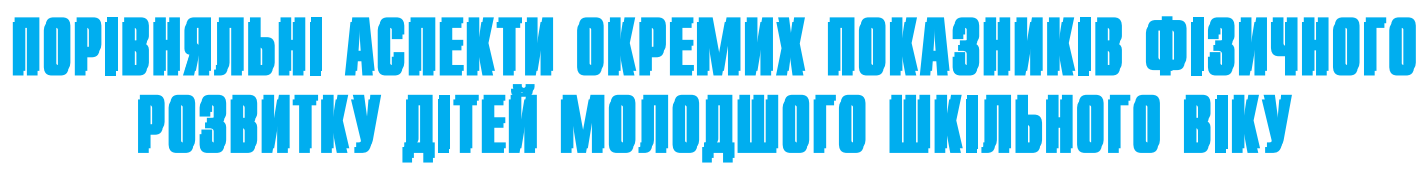

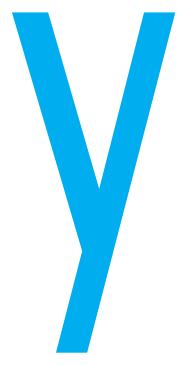

МОСКВяК Н.В.

Львівський національний медичний університет ім. Данила Галицького, м. Львів, Україна

Ключові слова: молодші школярі, фізичний розвиток, ріст, маса тіла, обвід грудної клітки. сучасній профілактичній медицині здоров'я дитячого організму розглядається як інтегральний показник, що формується внаслідок дії складного комплексу ендогенних та екзогенних чинників. Фізичний розвиток (ФР) є одним з провідних критеріїв здоров'я, що зумовлює необхідність проведення популяційного моніторингу процесів росту та формування організму дітей. Епохальні коливання базових характеристик притаманні багатьом фізіологічним і функціональним показникам, наприклад стану серцево-судинної системи, швидкості формування реакцій, мовних функцій тощо. Остаточно біологічні механізми акселерації поки не з'ясовані. Причини ї̈ виникнення пов'язують зі змінами генетичного матеріалу (потенціалу розвитку), системи харчування (збалансованості складу, якості і обсягу їжі), впливом комплексу клімато-географічних факторів, процесами урбанізації, що супроводжуються активною нейроендокринною стимуляцією функцій ЦНС внаслідок високого рівня стресу в умовах індустріального середовища [1-3].

Дослідження антропометричних ознак однорідних репрезентативних вибірок дитячих контингентів необхідні для планування комплексних профілактичних підходів до корекції здоров'я різних статевих та вікових груп дитячої популяції. Такі методи враховують динамічні коливання антропометричних показників, зумовлені територіальними соціально-
СРАВНИТЕЛЬНЫЕ АСПЕКТЫ ОТДЕЛЬНЫХ ПОКАЗАТЕЛЕЙ ФИЗИЧЕСКОГО РАЗВИТИЯ ДЕТЕЙ МЛАДШЕГО ШКОЛЬНОГО ВОЗРАСТА Москвяк Н.В.

Львовский национальный медицинский университет им. Данила Галицкого, г. Львов, Украина

Физическое развитие является одним из ведущих критериев здоровья, что обусловливает необходимость проведения популяционного мониторинга процессов роста и формирования организма детей.

Цель исследования предусматривала определение отдельных морфологических показателей школьников 8-летнего возраста г. Львова, а также установление различий между ними и антропометрическими параметрами детской популяции городских агломераций на территории других климато-географических зон Украины и соседних европейских государств. Материалы и методы. Исследованием было охвачено 459 детей (236 мальчиков и 223 девочки). Гармоничность физического развития оценивалась по значению индекса массы тела (ИМТ, индекса Кетле, биомасс-индекса) как соотношение массы тела (кг) и роста (м), возведенное в квадрат. Для изучения соматотипа применен расчет индекса пропорциональности между окружностью грудной клетки и длиной тела по М.В. Черноруцкому. Результаты. Среди обследованных городских школьников 8 лет доминирует контингент лиц со средним ростом, треть детей имела длину тела большую или меньшую относительно указанного диапазона. Средние значения ИМТ детей находятся в диапазоне нормы и составляют $(16,52 \pm 0,42) \kappa r / M^{2}$ и $(15,85 \pm 0,38) \kappa r / M^{2}$ среди мальчиков и девочек соответственно. Большая часть школьников 8 лет (54,5\%) имеет нормостенический тип конституции в соответствии с индексом пропорциональности между окружностью грудной клетки и длиной тела. Сравнение показателей массы тела и роста львовских школьников 8-летнего возраста с аналогичными параметрами их сверстников в других странах (Польша, Беларусь) указывает на отсутствие достоверных различий. Установленные закономерности свидетельствуют об увеличении антропометрических параметров детей в южных и западных областях по сравнению с аналогичными показателями их сверстников, проживающих на севере, востоке и в центре Украины.

Выводы. Целесообразно разрабатывать нормативные показатели антропометрических параметров детей согласно распределению административных единиц в соответствии с климатогеографическими зонами и учитывать при этом активные миграционные процессы, свойственные настоящему времени.

Ключевые слова: младшие школьники, физическое развитие, рост, масса тела, окружность грудной клетки.

() Москвяк Н.В. СТАТТЯ, 2019. 
календарного віку дітей здійснено згідно з рекомендаціями експертів B003: інтернет-сайт easycalculation-day/age.php. До групи дітей 8 років, що були обрані як індикаторна група, увійшли школярі віком від 7 років 6 місяців до 8 років 5 місяців 29 днів.

Антропометричні вимірювання молодших школярів проводились у медичних кабінетах школи з використанням стандартних наборів інструментів, що пройшли метрологічну повірку. Зріст (ЗР) вимірювався за допомогою вертикального ростоміра (з точністю до 0,5 см). Мaca тіла (МT) визначалась на медичних вагах (з точністю до 50 г). Обвід грудної клітки (ОГК) визначався прогумованою сантиметровою стрічкою (з точністю до 0,1 см). При вимірюванні грудної клітки у дівчаток 3 вираженими молочними залозами стрічка проходила над ними (по верхньому краю четвертого ребра).

Оцінювалася гармонійність фізичного розвитку за значенням індексу маси тіла (IMT, індекс Кетле, біомас-індекс) як співвідношення маси тіла (кг) і зросту (м), піднесеного до квадрату. Для вивчення соматотипу застосовано розрахунок індексу пропорційності між обводом грудної клітки та довжиною тіла за М.В. Черноруцьким [4].

Отримані дані опрацьовано за допомогою програм "MS Office Excel-2003" та STATISTIСА 6.0. Визначення вірогідності різниці між середніми показниками ФР у відповідних статевовікових групах здійснено відповідно до загальноприйнятних для медико-біологічних досліджень методів за t-критерієм Ст'юдента. Порогове значення статистичної вірогідності визначалося у межах не більших за $\mathrm{P}<0,05$.

Результати досліджень. Моніторинг основних антропо-

Таблиця 1

Усереднені значення антропометричних показників фізичного розвитку дітей 8 років

\begin{tabular}{|l|c|c|c|}
\hline \multirow{2}{*}{ Стать } & \multicolumn{3}{|c|}{ Антропометричні показники $(\mathrm{M} \pm \mathrm{m})$} \\
\cline { 2 - 4 } & Зріст, см & Маса тіла, кг & Обвід грудної клітки, см \\
\hline Хлопчики & $131,14 \pm 0,31$ & $28,62 \pm 0,26$ & $63,28 \pm 0,24$ \\
\hline Дівчатка & $129,75 \pm 0,34$ & $27,36 \pm 0,29$ & $62,45 \pm 0,29$ \\
\hline
\end{tabular}

метричних параметрів (зріст, маса тіла, обвід грудної клітки, індекс маси тіла) у багатьох країнах світу свідчить про зростання частки індивідуальних диспропорційних показників, що характеризуються як відхилення від місцевих стандартів ФР для дітей різних вікових груп. 3 огляду на це при вивченні закономірностей росту та розвитку дитячої популяції нами застосовано комплексний методичний підхід, який передбачав декілька взаємопов'язаних напрямків роботи.

За результатами дослідження 2015-2016 років опрацьовано середні значення антропометричних показників ФР дітей 8 років (табл. 1).

Аналіз даних соматометрії дозволив виявити дітей з ознаками прискореного ФР (високий зріст) та його затримкою (низький зріст), кількість яких відрізняється у відповідних статево-вікових групах. Загалом серед обстежених нами міських школярів 8 років домінує контингент осіб з середнім 3Р. Відповідо третина дітей мала довжину тіла більшу або меншу стосовно вказаного діапазону (рис. 1).

На основі проведених досліджень розроблено шкали регресії для оцінки ФР дітей 8-річного віку. При опрацюванні шкал регресії ФР (незалежна ознака - зріст (x), змінні ознаки - МТ (y) і ОГК (z) отримано рівняння регресії для 8-річних хлопчиків: $y=-54,97+0,695 x, z=10,67+$ 126-136 см, вище середнього - 137-142 см, нижче середнього - 143-150 см, низьким 116-119 см; для 8-річних дівчаток: $y=-57,86+0,657 x$ $z=4,953+0,5241 \times$ з середнім зростом 125-135 см, вище середнього - 136-140 см, нижче середнього - 120 124 см, високим - 141-149 см, низьким - 116-118 см

Серед рекомендованих експертами ВООЗ показників, що традиційно застосовуються в європейській профілактичній медицині при визначенні гармонійності ФР дітей, значна увага надається розрахунку IMT [5]. Середні значення IMT обстежених нами школярів 8 років визначаються у діапазоні норми (Платонова А. Г., 2012) становлять $(16,52 \pm 0,42) \mathrm{\kappa} / \mathrm{M}^{2}$ та $(15,85 \pm 0,38) \mathrm{кг} / \mathrm{M}^{2}$ серед хлопчиків і дівчаток відповідно. 
Разом з тим межі коливань мінімальних та максимальних показників (хлопчики - 12,20$21,89 \kappa г / \mathrm{M}^{2}$, дівчатка - 13,04-

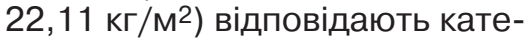
горії виснаження та ожиріння.

При вивченні гармонійності статури за індексом пропорційності між ОГК та ЗР нами встановлено, що більша частка школярів 8 років $(54,5 \%)$ має нормостенічний тип конституції. Дисгармонійна статура зі слабким розвитком (астенічний тип) симетрично представлена в обох групах дітей (хлопчики - 31,9\%, дівчатка $31,3 \%)$. Існує певна диспропорція між часткою осіб з дисгармонійною статурою 3 надмірним розвитком (гіперстенічний тип) поміж хлопчиків та дівчаток. Цей соматотип виявлено у $21,3 \%$ школярів чоловічої статі, що є у 3,5 рази більшим за показник дівчаток $(6,2 \%)$, а це, у свою чергу, вказує на переважання процесів граціалізації серед осіб жіночої статі (табл. 2).

На підставі співвідношення МТ і ЗР, оціненого згідно 3 індексом маси тіла, розподілу дітей на рівні за ЗР, а також показників соматотипу можна говорити про переважання гармонійного фізичного розвитку серед школярів 8 років.

Обговорення. Визначені нами показники морфологічного статусу молодших школярів $€$ достовірно вищими за середні національні показники 2013 року (за винятком МТ дівчаток та ОГК хлопчиків), а також попередні значення, які були встановлені на підставі власних досліджень у 20032005 роках [6, 7]. Це, у свою чергу, вказує на процеси акселерації фізичного розвитку дітей на теренах Західної України, що збігається 3 загальноєвропейськими тенденціями останнього десятиріччя. Підтвердженням вказаної закономірності є порівняння показників МТ та ЗР львівських школярів 8-річного віку з аналогічними параметрами їхніх однолітків в інших країнах. У 2010-2011 роках у м. Гомелі (Білорусь) проведено антропометричне обстеження 2894 учнів 30 З віком 7-17 років, серед яких група дітей 8 років складалася з 269 дітей (143 хлопчиків та 126 дівчаток). Середньостатис-

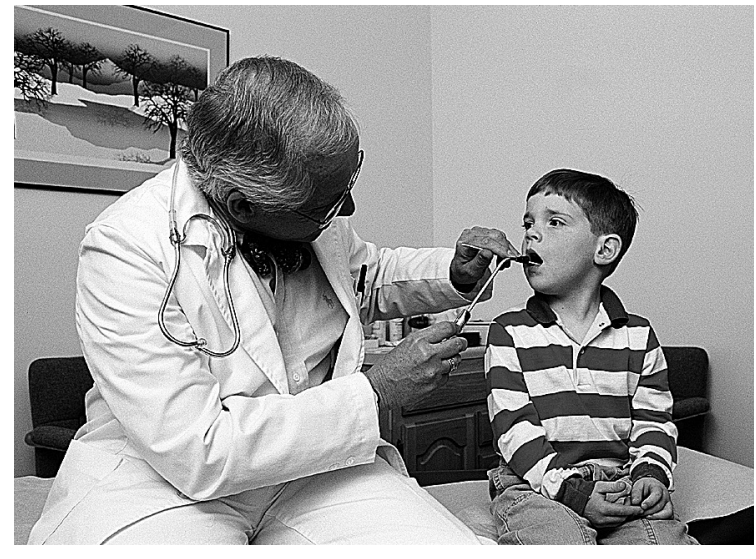

ГІГІЄНА ДІТЕЙ ТА ПІДЛІТКІВ

тичні параметри базових показників фізичного розвитку (ЗР, МТ, ОГК) білоруських школярів чоловічої статі становили 130,01 $\pm 0,43,29,09 \pm 0,43$, $63,55 \pm 0,41$, а серед школярок $-129,01 \pm 0,50,28,37 \pm$ 0,48, 62,96 \pm 0,47 відповідно. 3 наведених даних вірогідно нижчим $(P<0,02)$ від показників у м. Львові $€$ тільки зріст хлопчиків [8].

Дуже показовими є результати вивчення референтних значень зросту та маси тіла польських школярів (2008-2009 роки). Цей напрямок досліджень був фрагментом комплексного наукового дослідження "Опрацювання норм артеріального тиску для популяції дітей та молоді у Польщі", згідно з яким проводилися заміри показників фізичного розвитку 17573 хлопців та дівчат віком від 7 до 18 років [9].

\section{Розподіл показників фізичного розвитку хлопчиків \\ та дівчаток 8 років за зростом}

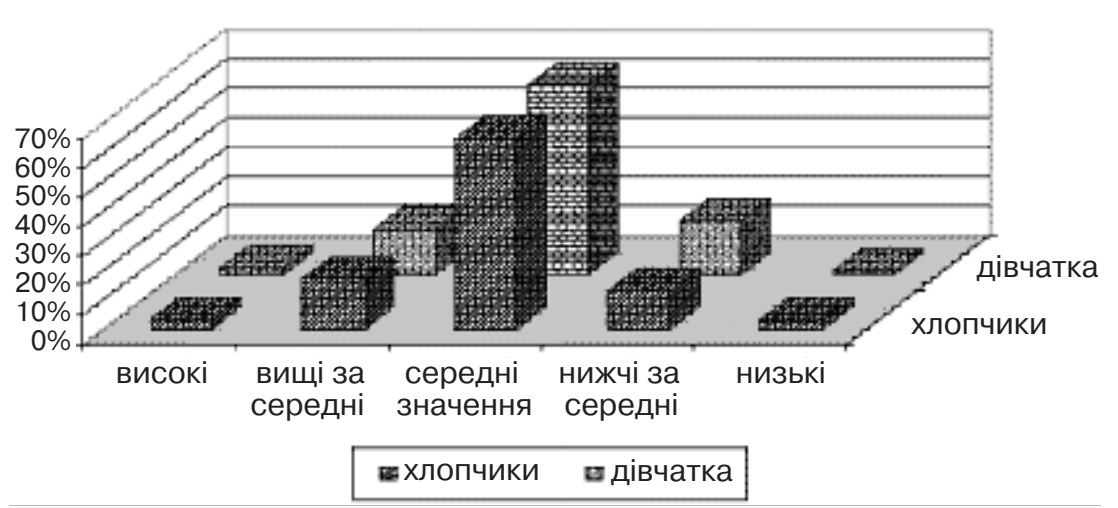

Таблиця 2

Показники соматотипу дітей 8 років (\%)

\begin{tabular}{|c|c|c|c|}
\hline \multirow{3}{*}{ Група дітей } & \multicolumn{3}{|c|}{ Соматотип } \\
\cline { 2 - 4 } & астенічний & нормостенічний & гіперстенічний \\
\hline Хлопчики & 31,9 & 46.8 & 21,3 \\
\hline Дівчатка & 31,3 & 62,5 & 6,2 \\
\hline
\end{tabular}

Чисельність контингенту 8річного віку становила 1404 соби (715 хлопчиків, 693 дівчинки). Середнє значення ЗР хлопчиків становило 130,60 \pm ток - 129,30 $\pm 0,23$ та $27,70 \pm$ 0,22 відповідно, тобто розбіжності антропометричних параметрів молодших школярів у двох сусідніх європейських деравах не є вірогідними.

динаміки показників ФР дітей за останні 40 років у м. Києві вказують на суттєве збільшензросту у сучасних школярів шкільного віку, які проживають на півдні України, характеризується високою дисгармонійного ФР за рахунок акселеративдецелерації. Найбільш виражені порушення дезадаптаційного характеру спостеріга-

Рисунок 1 
COMPARATIVE ASPECTS OF INDIVIDUAL INDICATORS OF THE PHYSICAL DEVELOPMENT OF PRIMARY SCHOOL AGE CHILDREN

Moskviak N.V.

Danylo Halytskyi Lviv National Medical University, Ukraine

Physical development is one of the leading health criteria that predetermine the necessity to perform population monitoring of the growth and formation processes in children.

The purpose of the study was to determine the individual morphological indicators of 8 years old schoolchildren in Lviv, as well as to establish the differences between them and the anthropometric parameters of the children's population from urban agglomerations on the territory of other climaticgeographical zones of Ukraine and neighboring European states.

Materials and methods. The study covered 459 children, among them 236 boys and 223 girls. The harmony of physical development was assessed by the value of the body mass index as the ratio of body weight in $\mathrm{kg}$ to height in meters squared. In order to study the somatotype, the calculation of the proportionality index between the chest circumference and the body length according to

M.V. Chernorutskyi was used.

Results. Among the surveyed urban 8 years old schoolchildren there is a predominance of a contingent of middle-height individuals; one third of children had a body length bigger or smaller than the specified range. Average values of BMI for children are in the range of $(16.52 \pm 0.42) \mathrm{kg} / \mathrm{m}^{2}$ and (15.85 \pm 0.38$) \mathrm{kg} / \mathrm{m}^{2}$ for boys and girls, respectively. A larger proportion of 8 years old schoolchildren (54.5\%) have normosthenic built according to the proportionality index between the chest circumference and the body length.

Comparison of BM and BL indicators of Lviv 8 years old schoolchildren with similar parameters of their peers in other countries (Poland, Belarus) indicates that there are no reliable differences.

The established regularities indicate an increase in the anthropometric parameters of children in the southern and western regions in comparison with similar indicators of their peers living in the north, east and in the center of Ukraine.

Conclusions. It is feasible to elaborate normative references of anthropometric parameters of children in accordance with the distribution of administrative units in the climatic-geographical zones and to take into account the active migration processes inherent in the present.

Keywords: primary school age children, physical development, height, body weight, chest circumference. лися у дівчаток препубертатного віку та у хлопчиків пубертатного віку [11]. Зміни антропометричних параметрів школярів м. Харкова протягом 1959-2002 років відбувалися не лінійно, а за певним трендом (коливанням) з чергуванням періодів прискорення і уповільнення збільшення ЗР і MT [12].

Вінницькі дослідники стверджують, що темпи акселерації та особливості прискореного росту та розвитку організму дітей і підлітків, які проживають у різних кліматичних зонах, $\epsilon$ адекватним критерієм оцінки

адаптації дитячого організму до умов довкілля [13].

На нашу думку, було цікавим зіставлення соматометричних показників львівських школярів 8-ми років як представників західного регіону з аналогічними значеннями їхніх однолітків, які проживають у великих містах на півночі (м. Київ), півдні (м. Одеса), сході (м. Харків) та у центрі України (м. Вінниця).

Найменше значення ЗР $(128,4 \pm 0,5)$ см) зафіксоване серед дівчаток м. Харкова, а найбільший показник (130,8 \pm $0,8)$ см) спостерігався у меш-

Рисунок 2

Показники зросту (см) дітей 8 років у великих містах України

136

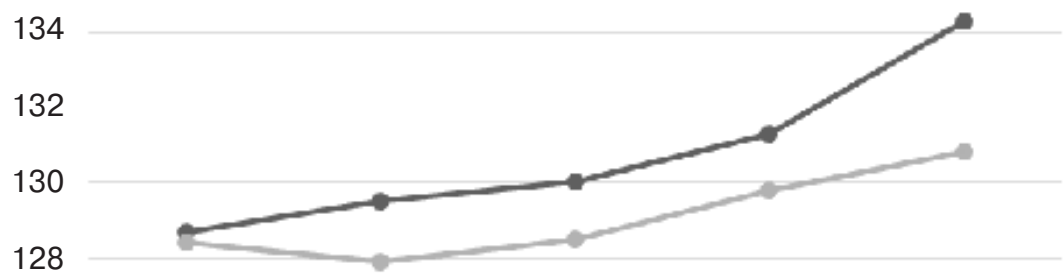

126

124

Харків Київ Вінниця Львів Одеса

канок м. Одеси. Аналогічна особливість виявлена серед контингенту хлопчиків, поміж яких мінімум становив $(128,7 \pm$ $0,4)$ см у харків'ян, максимум $(134,3 \pm 0,8)$ см в одеситів. ЗР львівських хлопчиків вірогідно перевищує параметр М. Харкова $(P<0,001)$, але $€$ нижчим за значення в м. Одесі $(P<0,001)$. Серед дівчаток не спостерігалося вірогідних розбіжностей у показниках ЗР.

Зіставлення показників МТ у різних клімато-географічних зонах нашої держави засвідчує відсутність вірогідної різниці у значеннях. Разом з тим, окреслюється чітка тенденція до збільшення параметрів на західних та південних територіях в обох статевих групах дітей (рис. 3).

За результатами порівняння замірів ОГК встановлено, що цей показник у львівських хлопчиків був на 2,08 см більшим, ніж у дітей м. Вінниці $(\mathrm{P}<0,05)$, а також на 3,52 cм $(\mathrm{P}<0,05)$ меншим від параметра школярів м. Одеси (рис. 4). Подібну закономірність встановлено й серед дівчаток. ОГК у м. Вінниці на 2,05 см $є$ меншим за значення у м. Львові, тоді як в одеських школярок перевищує отриманий нами результат на 2,05 cм (P>0,05). Показники київських школярів 
та вінницьких дітей вірогідно не відрізняються між собою. у столичному регіоні ОГК дітей 8 років $€$ меншим за параметри їхніх однолітків і у м. Львові, і в М. Одесі на 0,58 cм та 4,1 см $(\mathrm{P}<0,001)$ відповідно. Розбіжності між показниками ОГК дівчаток у м. Києві, м. Львові та м. Одесі становлять $-1,75$ см $(\mathrm{P}<0,05)$ та $-3,8$ см $(\mathrm{P}<0,001)$. Тобто ці значення вказують на ознаки граціалізації мешканок мегаполісу.

Отже, практично усі антропометричні ознаки $\epsilon$ вірогідно нижчими у дітей, які проживають в екологічно напруженому урбанізованому середовищі.

Встановлені закономірності свідчать про вищий рівень антропометричних параметрів дітей у південних та західних областях порівняно з аналогічними показниками їхніх однолітків, які проживають на півночі, сході та у центрі України. Це може бути зумовлено широким спектром проблем, серед яких провідне місце належить рівню урбанізації місцевості. Збільшення чисельності населення, значне забруднення довкілля, зумовлене особливостями функціонування потужного промислового комплексу і надмірним розвитком міської інфраструктури, що притаманно передусім східним та центральним областям нашої держави, впливають на адаптаційні резерви організму школярів молодшого шкільного віку. Саме тому усвідомлення загрози екологічної кризи має спонукати до систематичного моніторингу стану здоров'я i особливостей ФР дитячого населення у промислових регіонах

Серед інших причин, які, ймовірно, визначають розбіжність морфофункціональних показників дитячого організму, доцільно згадати низку інших ендогенних чинників: характер харчування та його відповідність віку, рівень фізичного, розумового, психоемоційного навантаження у молодшій школі, дотримання режиму дня, кліматичні умови, а також міграційні процеси й економічні проблеми, властиві сьогоденню.

\section{Висновки}

Проведені на відповідних територіях дослідження антропометричних параметрів мо- лодших школярів $€$ надзвичайно інформативними при вивченні особливостей ФР зазначеного вікового контингенту.

Моніторинг морфологічного розвитку комплексу показників здоров'я дітей на місцевому рівні необхідний для своєчасного виявлення несприятливих тенденцій та опрацювання дієвих медичних, гігієнічних та соціальних заходів, спрямованих на оптимізацію процесів росту та формування здоров'я дитячої популяції. Окремі території нашої держави відрізняються за характеристиками ландшафтних умов, своєрідністю господарської діяльності та побуту населення, що також потребує регіонального підходу до оцінки ФР дітей та підлітків. Відповідно до узагальнених рельєфних, клімато-погодних та еколого-гігієнічних особли-

Показники маси тіла (кг) дітей 8 років у великих містах України

32

30)

28

26

24

22

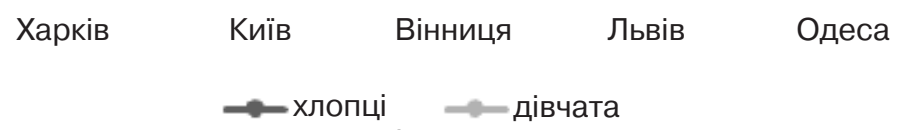

Показники обводу грудної клітки (см) дітей 8 років у великих містах України

68

66

64

62

60

58

56

Харків

Львів

Одеса 
складатися з відповідної кількості варіантів шкал регресії або центильних таблиць і кривих.

ЛІТЕРАТУРА

1. Hermanussen M., Godina E., Rbhli F.J. et all. Growth variation, final height and secular trend. Journal of Comparative Human Biology. 2010. Vol. 61 (4).

P. 277-284. doi:

10.1016/J.JCHB.2010.06.001.

2. Hermanussen M., Assmann C., Godina E. WHO Versus Regional Growth Standards. International Scientific Conference (Dedicated To 430-th Anniversary Of Vilnius University), June 29-th - July 1-st, Vilnius. Growth Charts: Local Versus International? Counted Versus Calculated. Vilnius, 2009. P. 18.

3. Година Е.3. Секулярный тренд: итоги и перспективы. Физиология человека. 2009. № 6. С. 128-135.

4. Дубровский В.И. Спортивная медицина: монография. Москва : Центр ВЛАДОС, 2002. 512 с.

5. Zhang L., Fos P.J., Johnson W.D. et al. Body mass index and health related quality of life in elementary school children: a pilot study. Health and Quality of Life Outcomes. 2008. № 9. P. 76-77. doi:

10.1186/1477-7525-6-77.

6. Moskvyak N.V., Mudra I.H. Peculiarities of Secular Trend of Physical Development Formation in Children Across Europe. Експериментальна та клінічна фізіологія та біохімія. 2017. Вип. 77. С. 17-23. https://doi.org/10.25040/ecpb2 017.01.017

7. Москвяк Н.В. Основні тенденції у фізичному розвитку дітей молодшого шкільного віку м. Львова. Довкілля та здоров'я. 2014. № 3. С. 19-23.

8. Мельник В.А., Козакевич Н.В., Козловский А.А. Таблицы оценки физического развития школьников города Гомеля: метод. рекомендации для педиатров, научных сотрудников, клинических ординаторов, аспирантов, студентов медицинских вузов. 2012. 32 c. URL: http://hdl.handle.net/GomSMU/2629

9. Kulaga Zb., Ròżdżyǹska A., Palczewska I., Grajda A., Gurzkowska B., Napieralska E., Litwin M. Siatki centylowe wysokos̀ci, masy ciala i wskaż- nika masy ciala dzieci i mlodzie y w Polsce - wyniki badania OLAF. Standardy medyczne.

Pediatria. 2010. T. 7. S. 690700. URL : www.standardy. $\mathrm{pl} /$ pediatria

10. Камінська T.M.

Ретроспективні дослідження фізичного розвитку школярів. Неонатологія, хірургія та перинатальна медицина. 2015. T. V, № 2 (16). С. 44-50.

11. Величко В.І., Бабій І.Л. Фізичний розвиток дітей шкільного віку півдня України. Здоровье ребенка. 2011. № 3 (30). URL : http://www.mifua.com/archive/article_print/21 921.

12. Даниленко Г.М., Бесєдіна О.А., Пашкевич С.А. Динаміка фізичного розвитку школярів міста Харкова.

Вісник Харківського

національного університету. 2002. № 546.

C. 88-91.

13. Осадчук Н.І., Сергета І.В. Фізичний розвиток дітей і підлітків та сучасні підходи до оцінки його гармонійності : монографія. Вінниця, 2014. $188 \mathrm{c}$.

\section{REFERENCES}

1. Hermanussen M., Godina E., Rьhli F.J., Blaha P., Boldsen J.L., Van Buuren S., Macintyre M., Assmann C. et all. Journal of Comparative Human Biology. 2010; Vol. 61 (4) : 277 284. doi: $10.1016 / J . J C H B$. 2010.06.001.

2. Hermanussen M., Assmann C. and Godina E. WHO Versus Regional Growth Standards. International Scientific Conference (Dedicated To 430-th Anniversary of Vilnius University), June 29-th July 1-st, Vilnius. Growth Charts: Local Versus International? Counted Versus Calculated. Vilnius, 2009. P. 18.

3. Godina E.Z. Fiziologiya cheloveka. 2009; 6: 128-135

(in Russian).

4. Dubrovskij V.I. Sportivnaya medicina: monografia [Sports medicine: monograph]. Moscow : Centr VLADOS; 2002: 512 p.

(in Russian).

5. Zhang L., Fos P.J., Johnson W.D., Kamali V., Cox R.G Zuniga M.A, Kittle T. Health and Quality of Life Outcomes. 2008; 9: 76-77. doi: 10.1186/14777525-6-77

6. Moskvyak N.V. and Mudra I.H. Experimental and
Clinical Physiology and

Biochemistry. 2017; 77: 17-23. https://doi.org/10.25040/ecpb2 017.01.017

7. Moskviak N.V. Osnovni tendentsii u fizychnomu rozvytku ditei molodshoho shkilnoho viku $m$. Lvova [The Main Trends in Physical Develeploment of Children of Lviv Primary Schools]. Dovkillia ta zdoroiya (Environment and Health). 2014; 3: 19-23 (in Ukrainian).

8. Melnik V.A., Kozakevich N.V. and Kozlovskij A.A. Tablitsy otsenki fizicheskogo razvitiya shkolnikov goroda Gomelya: metod. rekomendatsii dlia pediatrov, nauchnykh sotrudnikov, klinicheskikh ordinatorov, aspirantov, studentov meditsinskikh vuzov [Tables of Physical Development Assessment of School Children in Gomel City]. 2012 : 32 p. URL: http://hdl.handle.net/GomSMU/2629

(in Russian).

9. Kulaga Z., Ròżdżyǹska A., Palczewska I., Grajda A.,

Gurzkowska B., Napieralska E. and Litwin M. Siatki centylowe wysokos̀ci, masy ciala i wskaż nika masy ciala dzieci i mlodzie y w Polsce - wyniki badania OLAF. Standardy medyczne. [Percentile Charts of Height, Body Mass and Body Mass Index in Children and Adolescents in Poland - Results of the OLAF Study]. Pediatria. 2010; T. 7: 690-700. http:// www.standardy.pl/ pediatria (in Polish).

10. Kaminska T.M. Neonatology, Surgery and Perinatal Medicine. 2015; Vol. V. ; 2 (16) : 44-50 (in Ukrainian).

11. Velichko V.I. and Babii I.L. Zdorovje Rebenka. 2011; 3 (30). URL : http://www.mif-

ua.com/archive/article_print/21 921 (in Ukrainian).

12. Danylenko G.M., Besedina O.A. and Pashkevych S.A. Kharkiv National University Bulletin. Medicine. 2002 ; 546: 88-91 (in Ukrainian).

13. Osadchuk N.I. and Sergeta I.V. Fizychnyi rozvytok ditei i pidlitkiv ta suchasni pidkhody do otsinky yoho harmoniinosti: monografiia [Physical Development of Children and Adolescents and Modern Approaches to Assessing its Harmony: Monograph]. Vinnytsia ; 2014 : 188 p. (in Ukrainian).

Надійшла до редакції 27.01.2019 